\title{
From rattlesnake eggs to Alexander the Great: Edward Taylor's commonplace book
}

\author{
Amy Morris
}

'If you need to make a speech about a ripped coat or a bather's farthing, recount all the ancient customs of the Athenians from Lange's Florilegium. Tell us what happens among the Indians, and be sure to work in the customs of the Scythians.'

Such was the advice given to 'the inept orator' in a satirical tract published in Germany in 1642 . $^{1}$ The satire was pointed because school students in early modern Europe were trained to use, or better still, to create their own florilegia, by copying quotations into a commonplace book. Erasmus recommended storing selections systematically under subheadings, according to 'virtues and vices', and to 'loci communes' or 'stock themes' including 'old age and youth', 'sudden or strange death', 'monarchy and democracy'. ${ }^{2}$ Yet despite becoming 'one of the most widespread activities of the educated classes', the commonplace book was sometimes ridiculed because it encouraged far-fetched comparisons and displays of flashy but superficial knowledge: 'For, what though his Head be empty, provided his Common place-Book be full', mocked Swift of the hack writer. ${ }^{3}$ Thomas Fuller expressed a more moderate view: 'I know some have a Common-place against Common-place-books', he conceded, but many 'privately make use of what publickly they declaim against'. Fuller's widely shared opinion was that trusting only to memory was foolhardy: 'Adventure not all thy learning in one bottom, but divide it betwixt thy Memory and thy Note-books'. Fuller supplied a shipping metaphor to liken learning to a treasure or mercantile investment, but a kind of travelling was inherent to commonplacing. Text was transported from one book to another, such that material from different eras and places might be drawn together under diverse thematic categories.

\footnotetext{
${ }^{1}$ Johann Balthasar Schupp, Ineptus Orator, 3rd edn (Marburg: Caspar Chemlinus, 1642), p. 11. I thank David Lupher and Lawrence Morris for their help with Latin translation, and David Lupher, Kristin Cook, Ruth Abbott and Edward Holberton for their valuable feedback on earlier drafts of this essay.

${ }^{2}$ Desiderius Erasmus, De Copia Verborum (1513), summarized by R. R. Bolgar, The Classical Heritage and its Beneficiaries (Cambridge: Cambridge University Press, 1954), p. 274.

${ }^{3}$ Peter Beal, 'Notions in Garrison: The Seventeenth-Century Commonplace Book', in New Ways of Looking at Old Texts, ed. by W. Speed Hill (Binghamton, NY: Medieval \& Renaissance Texts \& Studies, 1993), pp. 131-47 (p. 131); Jonathan Swift, A Tale of a Tub, 3d edn corr. (London, 1704), p. 143.

${ }^{4}$ Thomas Fuller, The Holy State (Cambridge, 1642), pp. 175-76.
} 
Given the travel implicit within a commonplace book, what kinds of opportunities or adaptations did it offer to those who used it in remote places? The advice to 'Tell us what happens among the Indians' placed the Indies (East and West) at a geographical location of irrelevance to the immediate concerns of both tract and audience. On the English colonial frontier, however, information about American Indians, whom some believed to be descended from Scythians, was neither far-fetched nor irrelevant. ${ }^{5}$ By examining a commonplace book of historical and geographical material, compiled by an erudite reader who had migrated to the Anglo-American frontier, we will see how one New England scholar employed the European tradition of commonplacing to adapt his geographical imagination to new cultural coordinates.

New England educators imported the practice of commonplacing as a means of implanting theological knowledge. In a letter written circa 1672, copies of which circulated until at least 1723, the Reverend Thomas Shepard Jr advised his son, on entering Harvard College, to keep 'Collections' of excerpts from his reading in a 'Paper-book paged thro'out' using such headings as 'Faith' and 'hope'. 6 Cotton Mather instructed trainee ministers to enter daily 'Some Notable Thing, which in Reading you have newly met withal' into a blank book, assuring them that in so doing 'you will fix the Valuable Notion in your Mind: And in a few Years, you will have a Treasure' and 'agreeable Grains of Salt for all your Discourses'. ' Mather had sermons in mind as he interwove salt imagery from the Gospels with the classical tradition, which involved creating a treasury of sententiae for use in oratory. But, as his advice shows, a commonplace book was also a versatile reading companion: an empty book for storing material that had been read but not necessarily processed. Reportedly, Mather read quickly and 'reduc'd the Substance to his Common Places, to be review'd at Leisure'. ${ }^{8}$ It was because commonplace books were thus populated by semi-digested, miscellaneous text, that they were so easily satirized and abused: a polished orator or writer would not reproduce the odd juxtapositions found in his homemade book. On the other hand, a commonplace book was a literary work in its own right,

\footnotetext{
${ }^{5}$ Cotton Mather, Magnalia Christi Americana (London, 1702), bk 3, p. 11; Daniel Gookin (d. 1687), Historical Collections of the Indians in New England (Boston: Massachusetts Historical Society, 1792), p. 5.

6 'A Letter from the Revd Mr Thos Shepard to His Son at his Admission into the College', ed. by Frederick L. Gay, in Publications of the Colonial Society of Massachusetts, 14 (1913), 191-98 (p. 195).

${ }^{7}$ Cotton Mather, Manuductio ad Ministerium (Boston, 1726), p. 72.

${ }^{8}$ Thomas Prince, preface to Samuel Mather, in Life of [...] Cotton Mather (Boston, 1729), p. 3.
} 
albeit an informal one, which differed strikingly from most other early modern genres in its ability to host discontinuities, gaps, and far-fetched information, without comment.

After migrating to flee the restrictions of the Clarendon Code in 1668, Edward Taylor spent three years immersed in the scribal culture of Harvard College, where, not only were students encouraged to create commonplace books, they were obliged to copy out the college's laws, and had to produce many of their own textbooks by transcribing their tutor's notes. ${ }^{9}$ So, transcription was a natural tool for Taylor when, in 1671, he answered the call to serve as a minister in the 'remotest Swamps' of Westfield, Massachusetts. ${ }^{10}$ There he pastored a congregation, farmed, and pursued a surprising array of intellectual projects before his death in 1729. These included writing the poetry and religious prose that has now been published, and compiling an array of manuscript copybooks, organized according to different themes. Even if the family legend that Taylor created 'more than a hundred' handwritten books is untrue, transcription and note-taking were clearly fundamental to his studies, and important means of attenuating and inscribing his intellectual dislocation. ${ }^{11}$ The commonplace book in which Taylor entered geographical extracts thus proves a unique storehouse of rarities. For in it, he records his own and other experiences of strangeness within a mixed-up world of wonders, assembled and reconstituted from the pages of imported texts.

Writing on a blank page in one of Taylor's homemade books, Ezra Stiles described his prolific grandfather as 'an incessant Student', 'a great Historian and [in] every way a very Learned Man'. ${ }^{12}$ Yet only Taylor's poetry_and the religious prose used by critics to explicate it - have been made widely available. In the introduction to his critical edition of Taylor's 'Gods

\footnotetext{
${ }^{9}$ See Thomas Knoles and Lucia Zaucha Knoles, “'In Usum Pupillorum”: Student-Transcribed Texts at Harvard College before 1740', in Student Notebooks at Colonial Harvard: Manuscripts and Educational Practice, 16501740, ed. by Thomas Knoles, Rick Kennedy, Lucia Zaucha Knoles and others (Worcester: American Antiquarian Society, 2003), pp. 7-88 (p. 58).

${ }^{10}$ Edward Taylor to Samuel Sewall, 29 Sept. 1696, in 'The Pouring of the Sixth Vial: A Letter in a Taylor-Sewall Debate', ed. by Mukhtar Ali Isani, Proceedings of the Massachusetts Historical Society, 83 (1971), 123-29 (p. 125). ${ }^{11}$ Henry W. Taylor, 'Edward Taylor' in Annals of the American Pulpit, ed. by William Sprague (New York: Robert Carter, 1857) I, pp. 177-81 (p.179). Since Johnson interpreted one book in Taylor's probate inventory as a manuscript textbook, it is possible that others were also handwritten. See 'Taylor's Library', in The Poetical Works of Edward Taylor, ed. by Thomas H. Johnson (New York: Rockland editions [c.1939]), pp. 201-20 (p. 213). For a description of Taylor's extant manuscripts, see Donald E. Stanford, 'Appendix 2. Manuscripts', in The Poems of Edward Taylor, ed. by Stanford (New Haven: Yale University Press, 1960), pp. 502-21.

${ }^{12}$ See Charles W. Mignon, 'Some Notes on the History of the Edward Taylor Manuscripts', Yale University Library Gazette, 39 (1965), 168-73 (pp. 169-70).
} 
Determinations' and 'Preparatory Meditations', for instance, Daniel Patterson summarized various 'theological and biblical contexts [...] crucial for an understanding of [Taylor's] art', but made no mention of Taylor's non-theological literary pursuits. ${ }^{13}$ This emphasis on piety in the published materials has made those poems that don't fit the mold seem bizarre and uncharacteristic, such as 'Upon the Gyant', which barely mentions God, and the rather bawdy verses on 'Pope Joan'. 14 When read alongside the commonplace book of curiosities, however, which includes a page on giants and another on 'Impostures \& Lies', such worldly poems appear perfectly at home. Reshelving Taylor's commonplace book alongside his volume of 'Poetical Works', as I herein suggest, will restore a more varied and accurate picture of his intellectual life.

One reason for the neglect of Taylor's non-poetic, non-theological manuscripts has been the reluctance of literary critics to forego the lure of original writing in favour of examining copied, excerpted or anthologized material. But there has been a sea change, prompted in part by D. F. McKenzie's work on the sociology of texts, which has challenged literary critics to seek a more inclusive understanding of the relations between books and people. Moreover, now that postmodern views of authorship accord more 'interpretive weight' to 'the process of selecting', the compiler "might be rehabilitated as being on a par with the "author", as Ann Blair has suggested. ${ }^{15}$ In early New England studies, David D. Hall's work on social authorship has unravelled the notion of literary originality in the publication of sermons; Matthew P. Brown has argued for a 'reader-based, rather than author-based' literary history, so as to recognise the dominating role of imported reprints; and Meredith Neuman has demonstrated the importance of private note-taking in the religious self-fashioning of ordinary colonists. ${ }^{16}$ At the same time,

\footnotetext{
${ }^{13}$ Introduction to Edward Taylor's 'Gods Determinations' and 'Preparatory Meditations': A Critical Edition, ed. by Daniel Patterson (Kent, OH: Kent State University Press, 2003), p. 32.

${ }^{14}$ Edward Taylor's Minor Poetry, ed. by Thomas M. David and Virginia L. Davis (Boston: Twayne, 1981), pp. 211-16, 248-68. On the strangeness of Taylor's non-theological poetry, see Jeff Jeske, 'Edward Taylor and the Traditions of Puritan Nature Philosophy', in The Tayloring Shop: Essays on the Poetry of Edward Taylor in Honor of Thomas M. and Virginia L. Davis, ed. by Michael Schuldiner (Newark: University of Delaware Press, 1997), pp. 27-67 (pp. 56, 59).

${ }^{15}$ D. F. McKenzie, Bibliography and the Sociology of Texts (London: British Library, 1986); Ann Blair, Too Much to Know: Managing Scholarly Information before the Modern Age (New Haven: Yale University Press, 2010), p. 175.

${ }^{16}$ David D. Hall, Ways of Writing: The Practice and Politics of Text-Making in Seventeenth-Century New England (Philadelphia: University of Pennsylvania Press, 2008); Matthew P. Brown, The Pilgrim and the Bee: Reading
} 
commonplace books and what they reveal about reading and writing habits in early modern England have become a meeting point for historical and literary scholarship, with the investigations of Ann Blair and Richard Yeo dovetailing with case studies of the manuscript notebooks of such well-known writers as Bacon, Milton, and Boyle, and lesser-known figures including Clement Draper and Sir William Drake. ${ }^{17}$ Studies of the 'archaelogy of reading practices' and less formal 'ways of writing' have prepared the way for a richer reconsideration of Edward Taylor's archive. ${ }^{18}$

\section{Taylor's Commonplace Book of Rarities}

Written relatively late in life (circa 1703-25), Taylor's commonplace book of rarities illustrates his adaptation of the method to his practical needs and a remote perspective. ${ }^{19}$ The first part contains 'China's Description', which includes extensive extracts from the travel writings of the Jesuit missionary, Louis Le Comte, followed by thirteen pages of 'Reflections' ${ }^{20}$ As a précis and abridgement, 'China's Description' illustrates one use of note-taking and transcription which serves to extract the juice and render the book returnable to its owner (indeed, the original is not

Rituals and Book Culture in Early New England (Philadelphia: University of Pennsylvania Press, 2007), p. 20; Meredith Neuman, Jeremiah's Scribes: Creating Sermon Literature in Puritan New England (Philadelphia: University of Pennsylvania Press, 2013).

${ }^{17}$ Blair, Too Much to Know; Richard Yeo, 'Between Memory and Paperbooks: Baconianism and Natural History in Seventeenth-Century England', History of Science, 45 (March 2007), 1-46; Thomas Fulton, Historical Milton: Manuscript, Print, and Political Culture in Revolutionary England (Amherst: University of Massachusetts Press, 2010); Michael Hunter, 'Mapping the Mind of Robert Boyle: the Evidence of the Boyle Papers', in Archives of the Scientific Revolution: The Formation and Exchange of Ideas in Seventeenth-century Europe, ed. by Michael Hunter (Woodbridge: Boydell, 1998), pp. 121-36; Deborah Harkness, The Jewel House: Elizabethan London and the Scientific Revolution (New Haven: Yale University Press, 2007), on Draper. Kevin Sharpe, Reading Revolutions: The Politics of Reading in Early Modern England (New Haven: Yale University Press, 2000), on Blake.

${ }^{18}$ Roger Chartier, The Order of Books: Readers, Authors, and Libraries in Europe Between the Fourteenth and Eighteenth Centuries, trans. by Lydia G. Cochrane (Stanford: Stanford University Press, 1994), p. 22.

${ }^{19}$ Meditations 2.161B (1723) and 2.56 (1703), discussed below, either used the commonplace book of rarities or its sources. (All Meditation notes refer to the Patterson critical edition).

${ }^{20}$ Louis Le Comte, Memoirs and Observations [...] made in a Late Journey through the Empire of China (London, 1698). (This edition is specified in Taylor's 'Dispensatory', in Stanford, 'Appendix 2. Manuscripts', p. 509). The manuscript catalogued as 'China's Description and Commonplace Book' (henceforth abbreviated to CDCB) is also identified in Stanford's Appendix, p. 508. This is not to be confused with the 'Commonplace Book' that is described shortly thereafter, which Taylor began as a commonplace book with subheads, but filled in with letters and miscellaneous notes, pp. 513-16. References to Taylor's commonplace book in the text of this article refer to the book of rarities that is bound with 'China's Description', in the Yale Collection of American Literature, Beinecke Rare Book and Manuscript Library. 
listed in Taylor's probate inventory and may have been borrowed). The second part of Taylor's notebook is organized thematically as a commonplace book and shows transcription being used for a different purpose. It consists of interwoven citations from a few sources that must have been available to Taylor over a number of years, enough time to produce significant changes in handwriting and some duplication. ${ }^{21}$ Taylor collected these extracts under more than a hundred subheads, beginning with 'Man' (paginated ' 1 '), and continuing through 'Strange Births' and topics on family life, human arts such as 'Writing \& Books', 'fauna', followed by 'Rocks' and 'Trees', moving on to 'Idolatry', thence 'Monuments', 'Stately Palaces' and 'Mony', to 'Brave Exploits', and an assortment of topics including 'High Ways' and 'Bread', before finishing up with 'Ages', 'Murther' and 'Earthquakes \&c'. The book is not alphabetized, the pagination trails off, and there is no extant index. While not a traditional commonplace book in one sense, namely because it contains information instead of well-phrased arguments or sayings, Taylor's book is typical of how early modern readers customized the 'ever-protean commonplace book' to their own 'endlessly differentiated' purposes. ${ }^{22}$ In the process of making his book, Taylor redrew his imaginative relation to the globe. From his perspective at the edge of his civilization, Taylor's digest of strange customs, monuments, and animals from other distant provinces looked the perfect context in which to record a few local stories.

His most frequently cited source was Peter Heylyn's Cosmographie, followed by Patrick Gordon's Geographical Grammar, then Walter Raleigh's History of the World, and, some way behind, John Seller's History of England. The Magdeburg Centuries, John Speed's The Theatre of Great Britain, Cotton Mather's Decennium Luctuosum, and R. B.'s Admirable Curiosities receive occasional reference. There are single mentions of the Life of Bevis of Southampton, Locke's An Essay Concerning Human Understanding, William Derham's Physico-Theology, and The Historical and Political Monthly Mercury. ${ }^{23}$ Of the principal texts, Seller and Gordon are

\footnotetext{
${ }^{21}$ See for example CDCB, pp. 216-17; 283, 285.

${ }^{22}$ Earle Havens, Commonplace Books: A History of Manuscripts and Printed Books from Antiquity to the Twentieth Century (New Haven: Beinecke Rare Book and Manuscript Library, 2001), p. 9; David Allan, Commonplace Books and Reading in Georgian England (Cambridge: Cambridge University Press, 2010), p. 34.

${ }^{23}$ Taylor rarely specified editions, so the details that follow are either of first editions or editions that match Taylor's references and pagination: Peter Heylyn, Cosmographie in Four Books: Containing the Chorographie and Historie of the Whole World (London: Philip Chetwind, 1666). Patrick Gordon, Geography Anatomiz'd: Or, The Geographical Grammar, 4th edn (London, 1704); Sir Walter Raleigh, The History of the World (London, 1614); John Seller, The History of England (London, 1696); Ecclesiastica Historia [The Magdeburg Centuries] (Basel,
} 
not included in Taylor's probate library inventory, but folio editions of Heylyn and Raleigh occupy pride of place. Whether they were purchased, inherited, or received as gifts is unknown, but Taylor clearly used his notebook to amalgamate the wonders and curiosities he selected from these and other books. While he could have then composed the information in the mode of Cotton Mather's 'Biblia Americana' or Thomas Browne's Pseudodoxia Epidemica (London, 1646), it appears that, for Taylor, the commonplace book was primarily an end in itself.

In the process of amalgamation, Taylor's book drew upon the 'deep intertextual logic of collation' that structured sermon texts, note-taking and spiritual autobiography in New England. ${ }^{24}$ The reordering process that shaped Taylor's commonplace book shared features with typological exegesis, and the 'harmonizing' of the four gospels, both of which Taylor also practiced. ${ }^{25}$ But such theological collations were shaped by a salvific metanarrative, whereas Taylor's commonplace book lacked predictable arrangement. It juxtaposed subheadings, and grouped entries loosely underneath, without any conjoining discourse or explanation. Although the subheadings at the top of most pages were markers of order, they oversaw a higgledypiggledy collection. Taylor ruled most of the pages into two boxed columns, which he then filled with dense text from the top down, so they look like inverted phials (Figure 1). Often a new entry starts a new line, but to save space runs flush with the line above, and is minimally indented. Hyphenated words are common, stringing one line to the next. It thus becomes increasingly difficult to see where each item ends and the next one begins. Certain pages are crammed with text, while others remain only partly filled and may accommodate overflow from other pages. In this way, the pages resemble crowded boxes or drawers, a heap of similar-looking containers stacked with just enough associative logic to make the book navigable, with practice.

1574); Cotton Mather, Decennium Luctuosum (Boston, 1699); Bevis of Hampton (traditional, many versions, including The Famous and Renowned History of Sir Bevis of Southampton (London, 1689); John Locke, An Essay Concerning Human Understanding, 7th edn (London, 1715-16) I; John Speed, The Theatre of the Empire of Great Britaine (London, 1612); [Nathaniel Crouch], R[ichard/Robert] B[urton] (pseud.) Admirable Curiosities, Rarities, and Wonders in England, Scotland and Ireland (London, 1682); William Derham, Physico-Theology, (London, 1713); The Present State of Europe, or, the Historical and Political Monthly Mercury, a London periodical published 1690-1727. There are further unidentified citations. Of the cited texts, Raleigh, Heylyn, Magdeburg, Mather, and R. B. are in Taylor's library inventory.

${ }^{24}$ Neuman, p. 21.

${ }^{25}$ Edward Taylor's Harmony of the Gospels, ed. by Thomas M. Davis and Virginia L. Davis (Delmar, NY: Scholars' Facsimiles \& Reprints, 1983); Edward Taylor, Upon the Types of the Old Testament, ed. by Charles W. Mignon (Lincoln: University of Nebraska Press, 1989). 
Unlike this irregular arrangement, content in Taylor's four leading sources (also compilations) was carefully assimilated and presented in chronological and regional order. For Raleigh and Heylyn, encompassing the time and space of the world in a book was a magisterial accomplishment, a feat of grand narrative, which buried their controversial political involvement under quantities of ostensibly unrelated material. Seller's and Gordon's books were humbler in style and octavo or smaller in format. Yet by ordering their subjects by region and era, all four authors offered a clear structure that enabled their books to be consulted in a 'nonlinear' manner by 'bee'-like readers. ${ }^{26}$ Gordon presented information in such a formulaic way that each country had a subsection entitled, 'Rarities', aimed at readers like Taylor. Heylyn depicted his readers as tourists, able to 'visit' different 'places' in his compendium, the layout of which functioned spatially as a miniaturization of the globe: 'Running Titles on the top of each leaf, direct the Reader to a view of those Countreys which he is to Travel' (Figure 2). Besides geographical and name indexes, Heylyn appended an alphabetized table of 'things [...] not properly reducible to the other two'. With entries like, 'Tails of Sheep (and of no beast else) why used in Sacrifice;', 'Wolves destroyed in England, how.', and 'Oysters, growing on trees', this index was designed to pique a reader's curiosity, and to encourage one to read for diverting tidbits. ${ }^{27}$ Taylor copied this bit about the fruiting oysters, recording that they were farmed, using tree branches, in a curious (if not miraculous) way in the Gulf of Venice.

Reading back and forth was encouraged by Taylor's sources, but translated into the lines of Taylor's notebook the movement is thoroughly disorienting. The physical layout of the source texts provided a reassuring order, a mapped world, through which readers could wander without losing their bearings. In the notebook, however, predictable historical and geographical arrangement is jettisoned in favour of loosely associative subheadings. The technique of commonplacing inevitably involved prying extracts out of context: a page from Milton's commonplace book, for instance, collated entries from Gildas, Jean Bodin, Augustine, and Calvin under the heading 'Rex'. ${ }^{28}$ Yet when Edward Taylor reclassified information from history and geography books, by contrast, the dislocation became more literal. Frequently his chosen item's place in the world was so fundamental to its nature - the pyramid of Cheops, the pass of

\footnotetext{
${ }^{26}$ Brown, p. 14, p. xii.

${ }^{27}$ Heylyn, sigs. Iiiii1r, Kkkkk1r, L1112v, Mmmmm1v.

${ }^{28}$ Fulton, pp. 46-47, Fig. 2.3.
} 
Thermopylae, the holiness of the Ganges - that the reference dragged a section of the globe with it; and the price of the tentative new order offered by the category headings was a geographical soup.

In three consecutive pages in the middle, for example, the reader zigzags from a forest in Russia - in which a man falls into a hollow tree while looking for honey and is freed by a frightened bear - to a visual description (with measurements) of an immense Egyptian sphinx, followed by a Maine captivity narrative involving the miraculous provision of food. ${ }^{29}$ The respective categories to which these entries belong ('Things Strange', 'Monstrous Things', and 'Miracles') offer about as much in the way of organizing principles as the possibly random associations created by the material itself — the first story being a strange event involving food and captivity, the next a strange female monument, and the third a story about women, captivity and food. The full-page format of the captivity narrative, after many pages divided into columns, further suggests that Taylor may have written it separately and bound it in later. It is an uncertainty endemic to the commonplace book: the entries and subheadings are fragmented and potentially interchangeable. Yet, as in an experimental novel or Modernist poem, the adjacency of the entries generates associations, leaving the reader with the (oddly pleasurable) uncertainty as to whether these associations are constructed or serendipitous. It is impossible to know whether Edward Taylor consciously enjoyed the effect of these juxtapositions, but his notetaking went far to deconstruct neat source arrangements into new categorical jumbles.

Even Taylor's pragmatic compromise - between using his paper book consecutively (like a journal) and spatially (with pre-written topic headings) — pitted time and space against one other. The resulting strings of headings unwind, somewhat alliteratively, like chains of thought, occasionally interrupted by a wild card: 'Poyson', Serpents', 'Plagues \& Mortalities', 'Frogs \& Fish', 'Captives', 'Fish', 'Elephants'; or ‘ 'Great Armies', Sieges', 'Causwayes', 'Walls', 'Salt', 'Scarcity, \& Famine', 'Bread'. ${ }^{30}$ One effect of this wandering organization is the impression of a loss of centre. Although there can be no actual centre in time or on the surface of the globe, history books point teleologically to the present, and geography books are created by and for people living in a certain location. Despite Taylor's main sources being fiercely Protestant and

\footnotetext{
${ }^{29}$ CDCB, pp. 173-75.

${ }^{30}$ CDCB, pp. 211-15, 284-96.
} 
nationalistic, however, he did not give information about England, or even Europe, a prominent role in his commonplace book. Exotic customs are sensationalized according to the Eurocentric perspective expressed in Heylyn, in which forms of violence and promiscuity that were outlawed within Christendom were attributed to pagan cultures, such as murdering 'comely' strangers so that their souls would not depart, expecting virgins to earn their dowries through prostitution, or ritually deflowering young girls on an idol's 'bodkin'. ${ }^{31}$ But, aside from this tendency, Taylor's commonplace book de-centres Europe as a territory, by omitting, for instance, Heylyn's partisan renditions of recent European history.

Mostly ignoring recent politics, the commonplace book addressed ancient or ageless topics, including 'Of Parents and of Children', 'Idolatry', and 'Rains Strange', merging in its scope the long-ago of the chronicles and classics, with the frozen moment of anthropological observation, both temporalities that were distinct from the fragile contingency of Taylor's historical present. ${ }^{32}$ Nor did Taylor decentre England in order to promote New England, in the mode of his Boston colleagues, Increase and Cotton Mather. The overall impression given by Taylor's eclectic selections is one of distance: non-European places including Barbary, Tartary, and Peru are strongly represented, together with the classical civilizations of the Mediterranean. Although such a geographical 'concoction' implicitly identified Europe as the non-exotic centre, it also represented the world as an assemblage of remote margins and fragments, an appropriate textual location for a few stories from the New England frontier. ${ }^{33}$

The first of Taylor's references to New England occurs at the bottom of the first page, on 'Man', which suggests that Taylor intended his collection to supply a register of comparisons for recent, local experiences. The opening page starts with Adam, ' $\mathrm{y}^{\mathrm{e}}$ first man $\mathrm{y}^{\mathrm{t}}$ ever was [...] who was such a wonderfully excellent man', and then introduces 'all sorts of Deformities \& Evills' as the measure of 'Man'[s]' Fall. ${ }^{34}$ In his record, Taylor thus moves from the theoretical wonder of Adam straight to the margins, to list various examples of disfigurement. After noting a miraculous New Testament healing, he lists a few rare (but not supernatural) instances in which

\footnotetext{
${ }^{31}$ CDCB, pp. 312, 146, 251; Heylyn, pp. 857, 859, 891.

${ }^{32}$ CDCB, pp. 157, 251, 209.

${ }^{33}$ Benjamin Schmidt, Inventing Exoticism: Geography, Globalism, and Europe's Early Modern World (Philadelphia: University of Pennsylvania Press, 2015), p. 5.

${ }^{34}$ CDCB, p. 143.
} 
individuals overcame impairment through 'passion' or 'skilfull instruction'. These include Gordon's account of 'Thomas Schuviker who was born without hands \& feet \& yet could write curiously. A sheet of parchment wrote with 12 curious sorts of hands by him is kept at Mentz in Germany $[\ldots]$, ${ }^{35}$ After travelling from Paradise to Palestine to Naples to Germany, the list then ends in Simsbury, Connecticut, twenty miles from Taylor's home, where, as local records confirm, a young man named Joseph Bissell died in 1710. Taylor reports that on 'being opened', it was found that

[...] he had two Hearts \& two sets of Lungs. one heart among its midden place: \& sound: $\mathrm{y}^{\mathrm{e}}$ other more to $\mathrm{y}^{\mathrm{e}}$ side and it $\&$ its lungs were as it were shrunk $\&$ in a decay. Thus is a truth. He died at Simsbury in N England.

While the spatial arrangement of Taylor's list repudiates any clear narrative or argument, it provokes comparison and contrast: a hidden bodily 'excess' thus leads to death, whereas a visible bodily 'lack' leads to the multiplication of parts (twelve 'hands' on parchment, as it were). Taylor's physical arrangement, aided by the occasional Biblical reference, attaches these exceptional men to a theological metanarrative, although the list refuses to provide any discursive middle ground that might otherwise connect their stories. It offers instead the artistic suggestiveness of a collage. As a context for its specific New England example, then, this page and its heading on 'Man' simply paints a sky broad enough to overarch Bissell's story.

Taylor's assertion of 'truth', and his documentation of the date and place of Bissell's death, parallels his prior documentation of Gordon, who documented Schreiber, who documented himself. But such evidentiary concern only highlights the lack of any real proof. Once written down, and removed from time and place of origin, local rarities (even recent ones) become as vulnerable to doubt as reports from distant lands. In a personal recollection, inserted at the end of his section titled 'Ages', Taylor recalled a conversation with a woman he had once known in Warwickshire. She had described to him 'Rober ${ }^{t}$ Glover $\mathrm{y}^{\mathrm{e}}$ Martyre [...] $\mathrm{y}^{\mathrm{t}}$ was burnt 1555 [...] from her own knowledge of him \& observation when she was a little girle playing with others nigh his hall'. In his entry, Taylor continued, '[...] now allowing her to be about 5 or 6 years old, she was then 119 years old \& how long she lived after I never heard being come out

\footnotetext{
${ }^{35}$ Gordon, p. 126.
} 
of England'. ${ }^{36}$ Taylor's knowledge of Margret Orton was thus unmoored by his migration, but his memory found a home in this notebook, slotted under entries from published sources concerning longevity in Tartary, Brazil, Iceland, Sweden, and England, together with Galen's recommendations for a long life. Taylor's adjacent column on 'Time' featured calendar-keeping in pre-conquest Peru, the lack of it in Madagascar, and a note on the four-year rhythm of the ancient Olympic Games. His missing knowledge ('how long she lived after') simply underscored the distance between New England and his childhood home. From his new colonial outpost, Warwickshire seemed as remote as Madagascar, or Ancient Greece, or Anglo-Saxon England. Being so far from his cultural centre flattened Taylor's sense of relative time and space. Collating extracts about faraway and often non-European places, into a blank book, offered the rusticated Taylor the opportunity to re-envision the world and place himself in it. A commonplace book offered a flexible context that required no interpretation or assimilation of material into argument.

Taylor accentuated this accommodating feature of the genre by omitting critical commentary, even when it was offered in the source. One striking example is his collation of William Temple's account of a supposedly conversant parrot, which appears under the heading 'Birds'. Despite citing Locke as his source for Temple's account, Taylor omitted Locke's philosophical purpose in 'countenanc[ing] the Supposition' (or thought experiment) of a 'rational' parrot, and preserved only the anecdote for his book. ${ }^{37}$ Likewise, Taylor focussed on wonder when transcribing his quotations from Heylyn about the stubbornness of a South American pack animal: 'if $\mathrm{y}^{\mathrm{e}}$ burden be too much no blows nor violence will make him moove foot on till $y^{\mathrm{e}}$ load be lessened'. Taylor recorded this twice and both times omitted Heylyn's morally interpretive comment about the creature's 'acquaint[ance] with its own abilities'. 38 Similarly, when extracting from Seller, Taylor trimmed grave portents into nuggets of natural history. Under 'Trees', he noted, 'Edrick y $10 \mathrm{~K}$ : of Kent his people rebelled against, \& fought him at Maidstone \& slew him. $\mathrm{Y}^{\mathrm{e}}$ night before ye battle were heard Groans \& cries in $\mathrm{y}^{\mathrm{e}}$ aire. $\&$ all $y^{\mathrm{e}}$ Laurells thro'[o]ut $\mathrm{y}^{\mathrm{e}}$ country withered'. ${ }^{39}$ Unlike Seller, Taylor did not find this

\footnotetext{
${ }^{36}$ CDCB, p. 299.

${ }^{37}$ Locke, pp. 284-86, CDCB, p. 218, 220.

${ }^{38}$ CDCB, pp. 216, 217; Heylyn, p. 1063.

${ }^{39}$ CDCB, p. 235 (Figure 2); Seller, p. 52.
} 
occurrence a prompt to consider the politics of Edrick's reign. Seller's providential account of England's national story is thus broken and scattered like so much firewood across Taylor's categories, as Taylor pursued a more inclusive picture of 'this Earthy globe'. 40

Although some of Taylor's stories are akin to providence tales, reading like those in Increase Mather's Essay for the Recording of Illustrious Providences, Taylor's scope is markedly different and less focussed on New England. ${ }^{41}$ His notebook reads more like a literary Wunderkammer, where 'Rarities and Curiosities [...]' are catalogued in John Tradescant's sense, 'more for variety than any one place known in Europe could afford' (on the cabinet that formed the basis of the Ashmolean Museum). ${ }^{42}$ Like such collections, Taylor's notebook miniaturised history and geography into an eclectic gathering of curious things, drawn from different parts of the globe, dating to antique and modern times. Although the 'variety' of Taylor's material was appealing, it was also motivated by the hope, shared by Baconian natural philosophers, that collection, collation and corroboration would enable fuller understanding of the sublunary world.

\section{The Commonplace Book and Taylor's Meditative Verse}

Turning to Taylor's Meditations will show how the wonders that 'tended to cluster at the margins [...] of the known world' could play a spiritual role, for a minister who had internalized the remoteness of his own location. ${ }^{43}$ Despite differences in genre and purpose, there are many striking points of similarity between Taylor's commonplace book and his Preparatory Meditations. Both were ongoing projects in which process was more important than closure or completion. Both take the reader on rapid zigzag journeys across time and space, from the starting point of a given text or subheading. Both make compromises between consecutive and spatial orders, being composed in short segments that begin afresh after a page or two. Both

\footnotetext{
${ }^{40}$ Meditation 2.34 (1699), 1. 1.

${ }^{41}$ An example of overlap is the 'Strange recovery' of Jabez Musgrove, CDCB, p. 151, and Increase Mather, An Essay for the Recording of Illustrious Providences (Boston, 1684), pp. 38-39. For an account of recent, local providences, see Edward Taylor to Increase Mather, 22 Mar. 1683, Collections of the Massachusetts Historical Society, 4th Ser., 8 (1868), 629-30. 'Strange instances of Providences touching some [...]' is Taylor's only explicitly 'providential' subheading, CDCB, pp. 155-56.

${ }^{42}$ John Tradescant, Musaeum Tradescantianum: or, A Collection of Rarities (London, 1656), sig. A[8]v.

${ }^{43}$ Lorraine Daston and Katharine Park, Wonders and the Order of Nature, 1150-1650 (New York: Zone, 1998), p.

14. On eclectic collections, p. 273; on wonder as 'a goad to inquiry', p. 13.
} 
exude a collage-like suggestiveness by juxtaposing jarring material or imagery; in the poems this method becomes a deliberate means of using the inadequacy of the fallen world to shadow the divine. Taylor's method of mixing up world history and geography in his commonplace book has a parallel in the way his Meditations decentre the earthly concerns of their speaker. Not only do the poems make little reference to Taylor's geographical location, but their odd juxtaposition of earthly with religious language is designed to have an uprooting effect, that is, to reduce the phenomenal world to a distant glimmer of the spiritual truth at its core. The flattening of earthly differences that results from Taylor's formatting also features in his Meditations, where he deploys it for added rhetorical effect.

In comparison with divinity, he argues, the differences between earthly things become negligible, so that in the light of the Eucharist, 'George Nevills feast although prodigeous't were [...] Was but like th'indian broths of Garbagd deer/ With which the Netop entertains his guests / When almost starved'. ${ }^{44}$ Granted, this comparison relies on value distinctions in order to create the shock of collapsing them, but the technique demonstrates Taylor's awareness of the way in which one thematic category, 'feasts', can collate highly contrasting items. The zigzag of the comparison also shows how Taylor positioned his frontier location in relation to other forms of remoteness. Although Taylor was culturally closer to Neville, Medieval England was geographically and historically further away than the lives of New England Indians, from whom he was divided by a greater cultural rift; and in terms of wealth he had neither so much as Neville nor so little as the Indians. To return to the florilegium joke ('Tell us what happens among the Indians'), Taylor's comparisons here sketch a triangular relationship of connection and estrangement between himself, his historical culture, and his indigenous neighbours.

The wonder provided by far-fetched comparisons is pivotal to both Taylor's Meditations and his commonplace book. By treading the line between believable and unbelievable, these collected rarities exercised Taylor's capacity for wonder, which his Meditations then directed towards God. Among the natural curiosities that Taylor transcribed in his book are several local stories, including one that had been relayed to him by Samuel Mather of Connecticut. In it, a witness saw a squirrel defend itself against a rattlesnake using an egg it had stolen from the snake's nest: 'w[hi]ch way so ever $y^{\mathrm{e}}$ Rattlesnake assaulted $\mathrm{y}^{\mathrm{e}}$ squirrell, $\mathrm{y}^{\mathrm{e}}$ Squirrell would

\footnotetext{
${ }^{44}$ Meditation 2.159 (1722), 11. 26, 28-30.
} 
[put]y ${ }^{\mathrm{e}}$ Egg in its mouth out to $\mathrm{y}^{\mathrm{e}}$ Snake till at $\mathrm{y}^{\mathrm{e}}$ length $\mathrm{y}^{\mathrm{e}}$ Snake turns up \& dies. \& so ended $\mathrm{y}^{\mathrm{e}}$ strife. ${ }^{45}$ In his commonplace book, Taylor dramatizes the narrative without comment. In Meditation 2.161[B] (1723), he shapes it into a Plinyesque emblem, the egg being a weak analogy for the 'healing fruit' of Christ's grace:

It's better far then was the snakes eges found

By the poore squerrell and did arm itself

Therewith held in its teeth when th'snake did round

Assault it who held them unto this Elfe.

She tenderd the Eggs held in its mouth strange fate,

And so repelld away the Rattle snake.

(11. 25-30)

In this poem, Taylor found a providential application for an anecdote that was rattling around without one in his notebook. Although only the notebook version mentions the credibility of the witness (thereby acknowledging the incredibility of the tale), the poem relies on the story's continual teetering on the divinely controlled frontier between the impossible and the highly unlikely. This quality of 'strange fate' makes the story a useful analogy for the far-fetched truth of Man's redemption.

Meditation 2.161[B] also illustrates the similarity of effect between the thematic collation of disparate stories in Taylor's notebook and the strange associative slides within his poems. Starting with the text: 'As the apple tree among the trees of the wood, so is my beloved among the sons' (Canticles 2.3), Taylor developed the theme of apples, moving between Christ the 'apple tree' and the apple that the serpent persuaded Eve to 'mumble' 'in her Chops'. The roundness of the bitten egg, and the face-off with the snake offer associative links with Eden, and the encounter parodies Christic redemption by defeating a Devil-snake by threatening its offspring with death. Yet Taylor's simile also generates disruptive mismatches: an egg is not an apple, and the squirrel is an unexpected character. The poem lurches between Eden and colonial Connecticut, between timeless religious symbols of fruit, and an instance of strange behavior observed in local woodland creatures. Even the pronoun 'She' and the use of 'tenderd' blurs the boundary between the female squirrel who is tendering the egg(s) by holding them out, and the

${ }^{45}$ CDCB, p. 226. 
snake who feels tender about them. (To add another twist, rattlesnakes don't lay eggs, so something in the story is definitely awry). The next stanza leaves the animals behind, but performs a kinetic and aural glide from 'Rattle snake', to 'shake', in its first line: 'Oh shake the tree and make these apples fall / Into my Wicker Basket'. The Meditation's conclusion, 'I will Sing thy Grace with gracious strife' recalls '\& so ended the strife' in Taylor's notebook, suggesting that the notebook story shaped more of Taylor's Meditation than the one explicitly related stanza. The 'gracious strife' of Taylor's associative, alliterative and wandering imagery in the Meditations resembles the stringing together of headings within his commonplace book. The juxtaposition of imagery in his poems is also comparable to the assembling of diverse entries under generic subheadings. Both the Meditations and the commonplace book share a spontaneous, unravelling quality that counterpoints the disciplined regime of page layout and verse form. Through such commonalities, by a twist of 'strange fate', the disruptive dynamics of Taylor's note-taking find a spiritual purpose within Taylor's poems, and contribute to the speaker's effort to fit his individual experience into the overarching narrative of salvation.

But the relationship between the two genres and the manuscripts is complex. In his poetry, Taylor tended to frame worldly allusions negatively (including the snake egg and the feasts), trialling a comparison only to deem it ill-fitting. ${ }^{46}$ Reading his commonplace book reveals Taylor's fascination with things that he allowed only the baldest of mentions in his Meditations, which heightens the tension in his poetic allusions. Alexander the Great, for instance, one of the most prominent figures in the commonplace book, appears only twice in Taylor's religious verse. ${ }^{47}$ In 'Upon Wedlock, and Death of Children', Taylor describes marriage as stronger than a Gordian knot because 'No Alexanders Sword can it divide' ${ }^{48}$. In Meditation 2.115 (1713), which also begins with marital imagery, he names Alexander as the epitome of worldly success:

What art thou mine? am I espousd to thee?

What honour's this? It is more bright Renown

I ought to glory more in this sweet glee

Than if I'de wore greate Alexanders Crown.

\footnotetext{
${ }^{46}$ Examples include Meditations 2.31 (1699), 11. 1-12, and 2.67[A] (1705), 11. 1-6.

${ }^{47}$ Accounts of Alexander are found under fifteen different subheadings in CDCB.

48 Poems, ed. Stanford, pp. 468-70 (p. 468).
} 
Oh! Make my Heart loaded with Love ascend,

Up to thyselfe, its bridegroom, bright, and Friend. (11. 1-6)

The allusion to Alexander's fame is made in two words and then immediately left behind, as if the image's lack of development were demonstrating that worldly glories must remain at a distance, as mere stepping-stones towards truth. But the commonplace book conveys more about what Alexander meant to Taylor and suggests that he influenced Taylor's religious thinking more than the curt allusion implies. Taylor recorded the immense revenues that Alexander (and other potentates) received from their conquests. ${ }^{49}$ When, in stanza five the poet describes his love as a coin and 'tribute', therefore, he is sanctifying his own fascination with imperial wealth through an allusion to Christ's lesson on the Roman coin. ${ }^{50}$ The striking story of Alexander's siege of Tyre, which Taylor copied out of Raleigh and (a couple of pages later) out of Heylyn, is also suggestive: Alexander is 'presented [...] with a golden Crown' by the citizens of Tyre, but they refuse him entry, so he lays siege. Because the city was built 'on a rocky Island', Alexander 'fill[ed] up $\mathrm{y}^{\mathrm{e}}$ sea from $\mathrm{y}^{\mathrm{e}}$ land to it, $\mathrm{w}^{\text {th }}$ stones \& Rubbish of $\mathrm{y}^{\mathrm{e}}$ old town', built 'towers', 'overtopt' the walls, and 'took $y^{\mathrm{e}}$ City'. ${ }^{51}$ This method of attack parallels the unusual imagery of Meditation 2.115, in which the speaker seeks to 'ascend' to God, through being 'loaded' and 'fill[ed]' (11. 5, 54, 43). Although the poem's heap was to be one of 'love' not rubble, Taylor evidently found the idea appealing that worldly 'Rubbish' could be used as a means of raising one's thoughts heavenwards. This was his approach to the use of worldly allusions, including wonders, throughout his Meditations.

Taylor explores the meaning of wonders most directly in Meditation 2.56, (on John 15.24 'Had I not done amongst them the works, that none other man hath done, \&c.' 1703), and his poem fragment about the giant bones and teeth found in the Hudson Valley in 1705. Meditation 2.56 contains a two-stanza list of man-made wonders, the first four of which ('th'Pyramids, the Lake of Meris vast / The Pensile Orchards built in Babylon' and 'Psammitich's Labyrinth', 11. 26-28) are found in Taylor's commonplace book, copied from Heylyn and Raleigh. ${ }^{52}$ Although

\footnotetext{
${ }^{49}$ CDCB, pp. 269, 271.

${ }^{50}$ Matthew 22. 17-22.

${ }^{51}$ CDCB, pp. 283, 285. The entry from Heylyn is written in different ink and rougher handwriting than the entry from Raleigh, suggesting a significant time lapse between them.

${ }^{52}$ CDCB, pp. 267-68, 273.
} 
Taylor placed them in a verbal heap in his poem, his notebook entries described them as treasures, noting the marble beauty of the labyrinth, and the impressive engineering of the Egyptian reservoir. By casually stacking up allusions, the poem registers Taylor's fascination with these monuments, but at the same time seems to crush them to dust.

When read alongside the commonplace book, the poem's list of wonders feels springloaded, an odd blend of evocation and repression, even before Taylor formally dismisses all such 'Inventions' in stanza seven:

Might but my pen in natures Inventory Its progress make, 't might make such things to jump All which are but Inventions Vents or glory Wits Wantonings, and Fancies frollicks plump. Within whose maws lie buried Times, and Treasures Embalmed up in thick dawbed sinfull pleasures.

Taylor makes the case against his inventory of monuments by recommending an inventory of natural wonders. Yet by making things 'jump' the speaker elides himself with the manmade mechanical rarities he condemned in stanza six, in a list that culminated in a hopping party-piece: 'Mark Scaliota's Lock, and Key and Chain / Drawn by a Flea, in our Queen Betties reign' (1l. 35-36). Moreover, an inventory to shame an inventory, and the idea of 'buried Times, and Treasures / Embalmed up in thick dawbed sinfull pleasures' take us deeper into Taylor's mixedup commonplacing, rather than out of it. Both natural and artificial wonders are preserved in Taylor's book, including some very 'thick dawbed' accounts of 'sinful pleasures'. Was his collection of excerpts another example of 'Wits Wantonings', or, by virtue of being second-hand (and therefore available for monitory purposes), were his extracts the antidote? While demonstrating Taylor's ability to turn his fascination with rarities to a devotional purpose, this Meditation also poses a challenge to God to make spiritual deeds similarly pleasurable: 'Lord, feed mine eyes then with thy Doings rare'. Taylor was asking God to provide a spiritual replacement for the kind of 'eye candy' he found in Raleigh and Heylyn.

The kaleidoscopic variety that is embodied in Taylor's commonplace book becomes a source of philosophic contemplation in his unfinished fragment 'Upon the Gyant' ${ }^{53}$ Natural

\footnotetext{
${ }^{53}$ Minor Poetry, pp. 211-16.
} 
wonders rather than man-made are the topic of this poem's preamble, which considers the place of a human giant in the order of the natural world. Rather than introducing the giant as evidence of nature's corruption by sin, however, Taylor depicts 'monstrous Bulks of Human kind' (1. 99), together with the occasional poisonous dragon, as among the varied 'Fruits' borne by the tree of nature (1. 35). Other oversized rarities in the poem include a $130 \mathrm{lb}$ oyster shell kept at Leiden, the Theco tree (16 fathoms in girth), and legendary giants, Antaeus, Geryon and Ascapart. All these wonders are noted, with measurements, in Taylor's commonplace book. ${ }^{54}$ Introducing such examples from nature's 'Magazeens of Miracles' (1.37) Taylor explained that he would 'pick up ... a few':

To set mine Eyes on, thy bright selfe to view, As in a Looking Glass, to bring to thee In Admiration

Remarkably, the monsters are presented as mirrors of God's glory, suggesting that Taylor viewed nature as neutral or benevolent, rather than sinfully corrupt. ${ }^{55}$ But it was the balance of doubt and 'Credit' $(11.155,157)$, rather than good versus evil, that most interested Taylor in these examples of natural curiosities. The poem's speaker admitted having doubted 'Stories' of giants, suspecting that they 'oft a Molehill do a mountain make', but confirmed that the 'Gyants bones at Clavorack lately found' corroborated Native American accounts, and thus that those other 'large instances [...] have just ground' (11.101-08). Migrating to the estranged non-European world opened Taylor's mind to remote possibilities, including the idea that the pan-European tradition of giants might be based on fact. ${ }^{56}$

By narrating the speaker's change of opinion, 'Upon the Gyant' confirms that Taylor had been mentally storing accounts of wonders that he did not fully believe. The colourful entries in his book similarly push the limits of credibility, and yet for the same reason seize the imagination. In his poems, Taylor reframed these accounts to serve a moral or religious purpose, using the worldly curiosities to sketch forth a heavenly cosmography. In his commonplace book,

\footnotetext{
${ }^{54}$ CDCB pp. 214, 236, 211, 166 (under 'Fish', 'Trees', 'Serpents' and '[Gyants]' respectively); 'Upon the Gyant', 11. 39-47, 60-63, 87-92, 147.

${ }^{55}$ On monsters as admirable and natural, see Thomas Browne, Religio Medici (1642) pp. 29; Gottfried Willhelm Leibniz, Nouveaux Essais sur l'Entendement Human (written 1705, published 1765), bk 3, Ch. 3, item 14. On Taylor's blend of Platonic and Scholastic views of nature, see Jeske, pp. 27-67.

${ }^{56}$ Amy Morris, 'Geomythology on the Colonial Frontier: Edward Taylor, Cotton Mather and the Claverack Giant', $W M Q, 70.4$ (2013), 701-24.
} 
however, he transposed their purpose to highlight unusual events of the sublunary world, and the import of local interests. Although his fascination with Ancient civilizations and exotic customs marked Taylor's viewpoint as European, his proximity to American Indians (including a recent 'Gyant') threw him wildly out of orbit. Estranged from his familiar geographical and historical centre, Taylor chose to cut and shape new coordinates from his European textbooks. His book thus became an open-ended register in which to compare the marvels of the globe, and to see what might emerge through a new, non-narrative order.

At a time when, for some, the world was becoming 'disenchanted', while for others it yet proclaimed the divine, Taylor's commonplace book enabled him to keep all possibilities open. ${ }^{57}$ His book of rarities preserved and collated information, while transmuting published sources into a kind of 'broken knowledge', a scrapbook Wunderkammer. ${ }^{58}$ Wonder, created through variety and juxtaposition, was also vital to Taylor's Meditations. By tying together eclectic groups of stories and images in loose, associative bundles, or piling them into semi-ordered heaps, Taylor created a rough earthy 'fill' over which his thoughts could scramble towards God. Within the genre of English Protestant lyric, Taylor's Meditations thus retain an improvisational, unrefined aspect that easily fits the model of an incipient tradition of American homespun. It is far more likely, however, that such qualities were informed by Taylor's long-practised study methods, in combination with his unmoored perusals of Eurocentric history and geography textbooks.

\footnotetext{
${ }^{57}$ Max Weber, 'Wissenschaft als Beruf' (1919), translated as 'Science as a Vocation', in From Max Weber: Essays in Sociology, ed. and trans. by H. H. Gerth and C. Wright Mills (New York: Oxford University Press, 1946) pp. 129-56 (p. 139).

${ }^{58}$ Francis Bacon described 'wonder' at the divine as 'broken knowledge' in Of the Proficience and Advancement of Learning, Divine and Humane (London, 1605), p. 6.
} 